\title{
The insulin signalling system and the IRS proteins
}

\author{
M.F.White \\ Research Division, Joslin Diabetes Center and Harvard Medical School, Boston, Massachusetts, USA
}

Summary During the past few years, the insulin signalling system has emerged as a flexible network of interacting proteins. By utilizing the insulin receptor substrate (IRS)-proteins (IRS-1 and IRS-2), the insulin signal can be amplified or attenuated independently of insulin binding and tyrosine kinase activity, providing an extensible mechanism for signal transmission in multiple cellular backgrounds. By employing IRS-proteins to engage various signalling proteins, the insulin receptor avoids the stoichiometric constraints encountered by receptors which directly recruit SH2-proteins to their autophosphorylation sites. Finally, the shared use of IRS-proteins by multiple receptors is likely to reveal important connections between insulin and other hormones and cytokines which were previously unrecognized, or observed but unexplained. [Diabetologia (1997) 40: S 2-S17]

Keywords Insulin action, insulin signalling, insulin receptor substrate proteins, signal transduction.
Diabetes mellitus results from either a lack of insulin (insulin-dependent diabetes mellitus [IDDM]) or the failure to compensate for a diminished insulin response at various target tissues (non-insulin-dependent diabetes mellitus [NIDDM]). While there are important differences between IDDM and NIDDM, both diseases are characterized by high levels of circulating glucose, and both are accompanied in the long term by a set of debilitating sequelae, including retinopathy, nephropathy, neuropathy and vascular disease $[1,2]$. Insulin also has dramatic effects on human embryonic development: maternal hyperinsulinaemia

Corresponding author: M.F. White, Ph.D., Research Division, Joslin Diabetes Center, 1 Joslin Place, Boston, MA 02215, USA

A bbreviations: MAP, mitogen activated protein; GTP, guanosine 5'-triphosphate; TNFo, tumour necrosis factor alpha; IH1, IRS homology-1; IDDM, insulin-dependent diabetes mellitus; NIDDM, non-insulin-dependent diabetes mellitus; EGF, epidermal growth factor; PDGF, platelet derived growth factor; SH2, Src homology-2; PI, phosphatidylinositol; IGF-1, insulin-like growth factor-1; IRS, insulin-receptor substrate; IRR, insulin receptor-related receptor; GHR, growth hormone receptor; PTB, phosphotyrosine binding; IL, interleukin; IFN, interferon. causes excess fetal growth, and insulin-resistant fetuses display growth retardation [3, 4]. These alone are good reasons to study the molecular mechanism of insulin signalling; however, the insulin-receptor tyrosine kinase and its cellular substrates are important signalling systems to understand, and in their details reveal common mechanisms and overlapping pathways controlling cellular growth and metabolism.

The mechanism of insulin action is a challenging problem. For 50 years since the discovery of insulin, the study of insulin action focused on the metabolic changes that occur during insulin stimulation - first at the whole animal level and later at the cellular level $[3,5]$. These studies demonstrated that processes such as glucose uptake, lipid synthesis, protein synthesis, and glycogen deposition are controlled by insulin; but the principal cause of insulin resistance has not been identified. Recently, reduced insulin-receptor tyrosine kinase activity has been observed in cells from NIDDM patients, and various mutations have been identified in patients with severe insulin resistance [4-6]. As NIDDM appears to result from a complex set of genetic and environmental inputs, the principal causes of NIDDM have been difficult to discover by genetic means. A molecular understanding 
of the cellular mechanism of insulin action may ultimately elucidate the pathophysiology of NIDDM, and lead to the design of efficacious, safe and convenient interventions.

\section{A ssembly of signalling complexes by tyrosine kinase receptors}

Following the initial discovery of tyrosine kinases, and their role in the regulation of cellular metabolism and growth, the search for order and specificity of this class of enzyme was confounded by their apparent catalytic promiscuity. The purified receptors for insulin, epidermal growth factor (EGF), platelet derived growth factor (PDGF) and others could phosphorylate almost any protein mixed with them in the presence of [ $\left.{ }^{32} \mathrm{P}\right]$ ATP [7]. However, the specificity of various tyrosine kinases in cells became apparent during immunoprecipitation and immunoblotting with antiphosphotyrosine antibodies $(\alpha \mathrm{PY})$. In cells, the insulin receptor was almost too restricted, and for many years the only tyrosine phosphorylated protein recognized during insulin stimulation was the $\beta$-subunit of the receptor itself $[8,9]$. It was eventually appreciated that ligand-induced autophosphorylation of most growth factor receptors mediated the direct association of various signal transduction proteins $[10,11]$.

The common theme among all tyrosine kinase signalling mechanisms centres on hormone/growth factor/cytokine-induced dimerization, and downstream heterologous protein-protein interactions initiated by the activated receptor. Ligand binding mediates the dimerization of receptor subunits to juxtapose adjacent catalytic domains, so multiple tyrosine residues on the closely opposed receptors are phosphorylated, usually in trans, by the intrinsic or associated tyrosine kinase [12]. Signalling specificity begins with the selection of appropriate tyrosine residues. This step is largely directed by the specificity of the catalytic domain in the complex, and involves the interaction between positively charged residues in the catalytic pocket with negatively charged residues near the tyrosine residue [13]. Specificity is further controlled by the selective binding of the autophosphorylation sites to proteins with complementary Src homology2 domains (SH2-protein) [14]. The $\mathrm{SH} 2$ domain is composed of approximately 100 amino acid residues which bind to phosphotyrosine in a specific amino acid sequence context [14]. Some proteins in this signalling complex are activated during binding to the phosphorylated motifs, whereas others are activated by tyrosine phosphorylation that occurs in the complex; the subcellular distribution of the SH2-protein may also contribute to signalling specificity. Irrespective of the exact mechanism, the characteristic biological response of each factor arises in large part from the cohort of interacting SH2-proteins $[10,14]$.
For example, the activated receptors for EGF and PDGF bind to the $\mathrm{SH} 2$ domains in the phosphatidylinositol (PI) 3'-kinase, p21 ${ }^{\text {ras }}$-GAP, phospholipase $\mathrm{C} \gamma$, Grb2/Sos, cytoplasmic tyrosine kinases like c-fyn and c-src, and other SH2-proteins in various cellular backgrounds [15].

The assembly of a similar signalling complex around the insulin receptor was always difficult to show. However, for insulin and the insulin-like growth factor-1 (IGF-1) receptor, autophosphorylation activates the catalytic domain, and the formation of the signalling complex occurs largely through the phosphorylation of the insulin-receptor substrate (IRS)-proteins, Shc, and other substrates. Phosphorylated IRS-1 activates the PI 3'-kinase during binding to the $\mathrm{SH} 2$ domains in its $\mathrm{p} 85 \alpha$ regulatory subunit [16]. Other SH2-proteins, including SHP2 [17], GRB-2 [18], and nck [19], associate with IRS-1 to mediate the pleiotropic insulin response. Tyrosine phosphorylation of Shc stimulates the binding of Grb2/ Sos, and contributes to the IRS-independent activation of p21 $1^{\text {ras }}$ [20]. Moreover, other substrates such as pp60 $60^{\mathrm{IRS}}$ may also contribute to the insulin response in various tissues.

\section{The insulin receptor}

Introduction. The insulin receptor is present in virtually all vertebrate tissues, although the concentration varies from as few as 40 receptors on circulating erythrocytes to more than 200000 receptors on adipocytes and hepatocytes. The receptor gene is located on the short arm of human chromosome 19, is more than 150 kilobases in length and contains 22 exons which encode a $4.2 \mathrm{~kb}$ cDNA [21]. The insulin receptor is composed of two $\alpha$-subunits that are each linked to a $\beta$-subunit and to each other by disulphide bonds (Fig.1 A). Both subunits are derived from a single proreceptor by proteolytic processing at a cleavage site consisting of 4 basic amino acids. There is one site of alternative splicing surrounding exon 11 which results in two receptor isoforms differing by 12 amino acids near the $\mathrm{COOH}$-terminus of the $\alpha$-subunit (Fig. 1 A). The mature heterotetramer $\left(\alpha_{2} \beta_{2}\right)$ contains complex $\mathrm{N}$-linked carbohydrate side chains capped by terminal sialic acid residues and migrates with a molecular mass of $300-400 \mathrm{kDa}$ by sodium dodecyl sulphate-polyacrilamide gel electrophoresis (SDS-PAGE). The $\alpha$-subunits are located entirely outside the cell and contain the insulin binding site(s), whereas the intracellular portion of the $\beta$ subunit contains the insulin-regulated tyrosine protein kinase (Fig. 1 A). The insulin receptor family contains two other structurally related molecules, the IGF-1 receptor, and the insulin receptor-related (IRR) receptor, an orphan receptor for which no ligand has yet been identified [22]. This family shares 


\section{$\alpha$-Subunits}

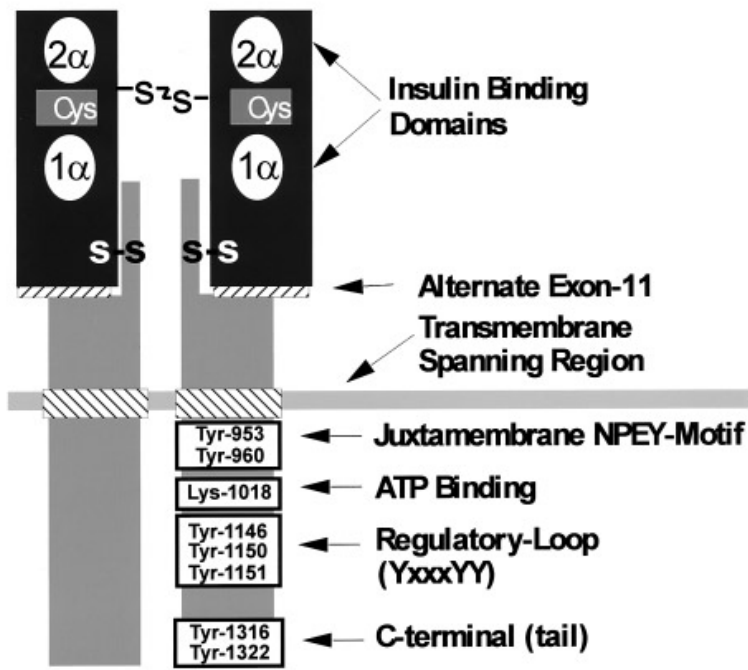

\section{$\beta$-Subunits}

A

Fig. 1. A . Schematic diagram of the insulin receptor tetramer. The membrane is represented by a horizontal line. Insulin binding sites are shown in the $\alpha$-subunit, and the autophosphorylation sites are listed in the $\beta$-subunits. B . Representation of the structure of the catalytic domain of the insulin receptor. The structure is composed of a small upper loop and a larger lower loop, which correspond to the ATP binding and catalytic domains, respectively. The lysine residue that binds ATP (upper loop), the three phosphorylation sites in the regulatory loop and the four positively charged residues that mediate phosphorylation site selection are indicated. A single peptide sequence links the upper and lower domains.

more than $80 \%$ amino acid sequence identity in the kinase domain but has low amino acid sequence identity in the extracellular domain, consistent with their ligand preference.

Insulin binding. Following its release by the beta cells of the pancreas, insulin binds to its receptor on the surface of most cells. Before insulin binding, the $\alpha$ subunits apparently exert a negative effect upon the kinase, as removal of the extracellular domain by enzymatic digestion or mutagenesis constitutively activates the kinase [23-25]. Although disulphide bonds stabilize the interactions between two $\alpha$-subunits, insulin binding activates the receptor through a mechanism thought to be analogous to that for monomeric receptors. In particular, biochemical and structural studies on the growth hormone receptor (GHR) provide elegant support for this hypothesis: growth hormone behaves as a divalent ligand which crosslinks two GHR molecules [26, 27]. The notion that dimerization of adjacent receptor subunits leads to activation of the associated tyrosine kinases has gained general acceptance [28-30].

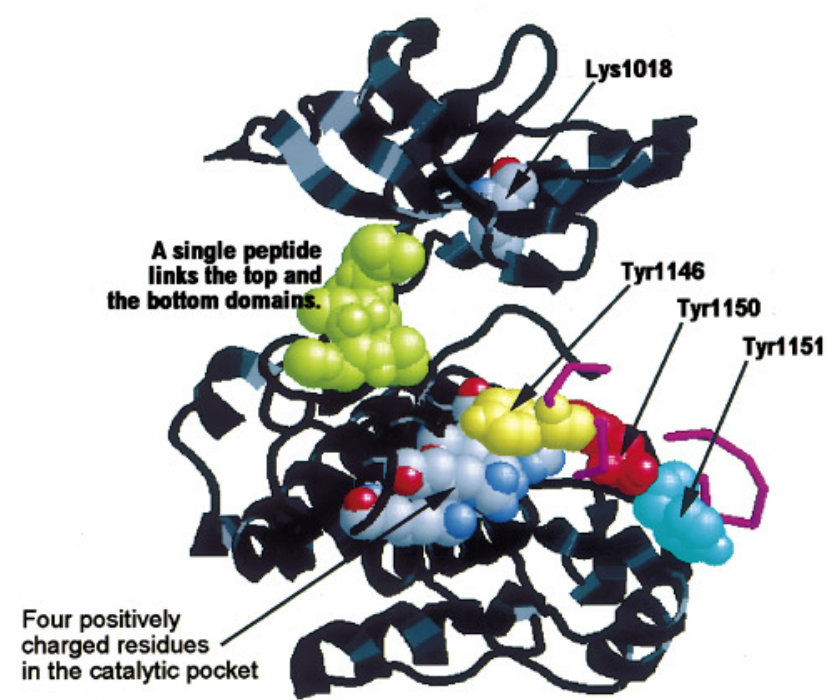

B

Although adjacent insulin receptor molecules are covalently linked during biosynthesis and processing, insulin binding apparently modifies the $\alpha$-subunit dimer which mediates trans-autophosphorylation between the $\beta$-subunits [31-34]. Historically, the stoichiometry of insulin binding has been contentious, and reported to be between 1 and 2 insulin molecules per receptor tetrameter [35]. Recently, a conceptual model to explain these data has been proposed [35]. Each $\alpha$-subunit contains two distinct insulin binding domains with a weak degree of internal redundancy flanking the single cysteine-rich domain, designated site $1 \alpha$ and site- $2 \alpha$ (Fig. 2B). The residues encoded by exon- 2 , especially $\mathrm{Phe}^{89}$ compose site- $2 \alpha$, and the residues encoded by exons 6 and 7 compose site- $1 \alpha$ [35]. Site- $1 \alpha$ and site $2 \alpha$ may fold as a $\beta$-sheet flanked by two $\alpha$-helices, which associates as a pseudosymmetrical dimer within each $\alpha$-subunit [36]. Experimental and naturally occurring mutations in the $\alpha$ subunit suggest that both regions contribute independently to insulin binding [35]. To complement this hypothesis, the insulin molecule itself also has two distinct receptor binding domains: site-1 is composed of a dozen invariant residues from both the $\mathrm{A}$ and $\mathrm{B}$ chain $\left(\mathrm{G}^{\mathrm{A} 1}, \mathrm{E}^{\mathrm{A} 4}, \mathrm{Q}^{\mathrm{A} 5}, \mathrm{Y}^{\mathrm{A} 19}, \mathrm{~N}^{\mathrm{A} 21}, \mathrm{~V}^{\mathrm{B} 12}, \mathrm{~T}^{\mathrm{B} 16}, \mathrm{G}^{\mathrm{B} 23}\right.$, $\mathrm{F}^{\mathrm{B} 24}, \mathrm{~F}^{\mathrm{B} 25}$ and $\mathrm{Y}^{\mathrm{B} 26}$ ); site-2 coincides with the hexamerization surface of insulin ( $\mathrm{L}^{\mathrm{A} 13}$ and $\mathrm{L}^{\mathrm{B} 17}$ ) (Fig. 2A). Presumably, two independent sites each on insulin and the insulin receptor mediate crosslinking between the covalently linked $\alpha$-subunits (Fig.2B). This hypothesis is fashioned after a similar model describing dimerization of the growth hormone receptor by growth hormone [35]. The model unifies the mechanism of insulin receptor activation with the general hypothesis proposed earlier for other systems [37]. The ligand sensitivity of chimeric receptors 

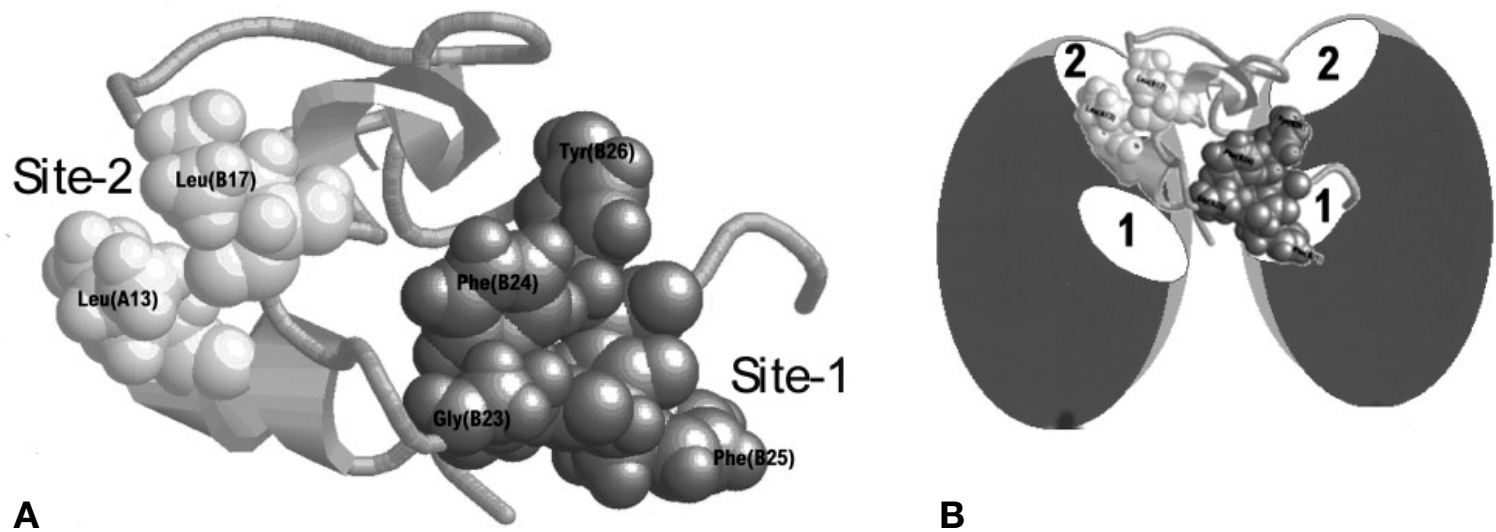

B

Fig. 2A , B . Representation of the structure of insulin and its hypothetical binding to the $\alpha$-subunits of the insulin receptor A. The insulin molecule is rotated to show the relative locations of the receptor binding sites: 1 and 2. Some amino acid residues in each site are shown for orientation. B. A cartoon depicting the hypothetical mechanism by which one insulin molecule is thought to modify the covalent insulin receptor dimer

composed of the ligand binding and catalytic domain of the EGF and insulin receptors supports this hypothesis [38, 39].

The transmembrane spanning region. The external ligand binding domain of the insulin receptor is linked to the tyrosine kinase by a single transmembrane segment which has broad tolerance for amino acid substitutions [40, 41]. However, the insulin receptor is constitutively activated by substitution in the transmembrane segment from the oncogene v-erbB-2 which contains a $\mathrm{Val}_{664} \rightarrow \mathrm{Glu}_{664}$ mutation [42]; an analogous point mutation $\left(\mathrm{Val}_{938} \rightarrow \mathrm{Asp}_{938}\right)$ in the transmembrane segment of the insulin receptor also partially activates the receptor kinase [43]. Apparently, this region stabilizes the insulin-induced conformational change, which is analogous to the receptor-receptor contacts in the ligand activated growth hormone receptor [44]. Thus, mutations that stabilize an interaction between the membrane spanning region of adjacent receptors may cause constitutive activity.

The tyrosine kinase. Insulin binding activates the tyrosine kinase, leading to autophosphorylation of tyrosine residues in several regions of the intracellular $\beta$-subunit, including $\mathrm{Tyr}_{960}$ in the juxtamembrane region; $\mathrm{Tyr}_{1146}, \mathrm{Tyr}_{1150}$, and $\mathrm{Tyr}_{1151}$ in the regulatory loop; and $\mathrm{Tyr}_{1316}$ and $\mathrm{Tyr}_{1322}$ in the $\mathrm{COOH}$-terminus [45-48]. The tyrosine kinase activity of the receptor is crucial for insulin action: site-directed point mutations in the ATP binding domain destroy ATP binding (and thus abolish kinase activity) and abrogate insulin signalling in cultured cells $[49,50]$; naturally occurring mutations of the insulin receptor which inhibit kinase activity are associated with severe insulin resistance $[51,52]$. Thus, activation of the insulin receptor tyrosine kinase and the phosphorylation of cellular substrates predominates as an important mechanism of insulin signal transduction.

Autophosphorylation of all three tyrosine residues in the regulatory loop (Fig. 1 A,B) activates the kinase 10 to 20-fold [53]. Mutation at one, two or three tyrosine residues in this region progressively reduces insulin-stimulated kinase activity and results in a parallel loss of biological activity [54, 55]. In many cultured cell lines, the regulatory region is only bis-phosphorylated during insulin stimulation, which may limit the amplitude of the insulin response or the selection of phosphorylation sites in target proteins. However, tris-phosphorylation predominates in rat hepatocytes suggesting a mechanism for tissue-specific up-regulation of the insulin signal [56].

In addition to the regulation of the kinase, recent evidence suggests that the regulatory-loop may bind SH2-proteins. SHP2 associates with $\mathrm{Tyr}_{1146}$ in the regulatory loop of the $\beta$-subunit [57]. This may provide a more stable link between the insulin receptor and IRS-1 than can be obtained through other mechanisms. Furthermore, this association may play a role during insulin-stimulated glucose uptake [57].

The juxtamembrane region. The intracellular juxtamembrane region of the insulin receptor $\beta$-subunit is essential for signal transmission as it mediates substrate selection, presumably by engaging the phosphotyrosine binding (PTB) domains in the IRS-proteins and Shc (Fig. 3). This region is encoded by exon 16 of the insulin-receptor gene and contains several serine phosphorylation sites and at least one tyrosine autophosphorylation site in an $\mathrm{NPXY}_{960}$-motif [45]. Substitution of $\mathrm{Tyr}_{960}$ with other amino acids impairs receptor signal transmission in vivo, even though the kinase activates normally; this appears to be due to an inability of these mutant receptors to mediate the phosphorylation of IRS-1 and Shc, as the tyrosine kinase is activated normally in all these cases $[58,59]$. Overexpression of IRS-1 with these mutant receptors 


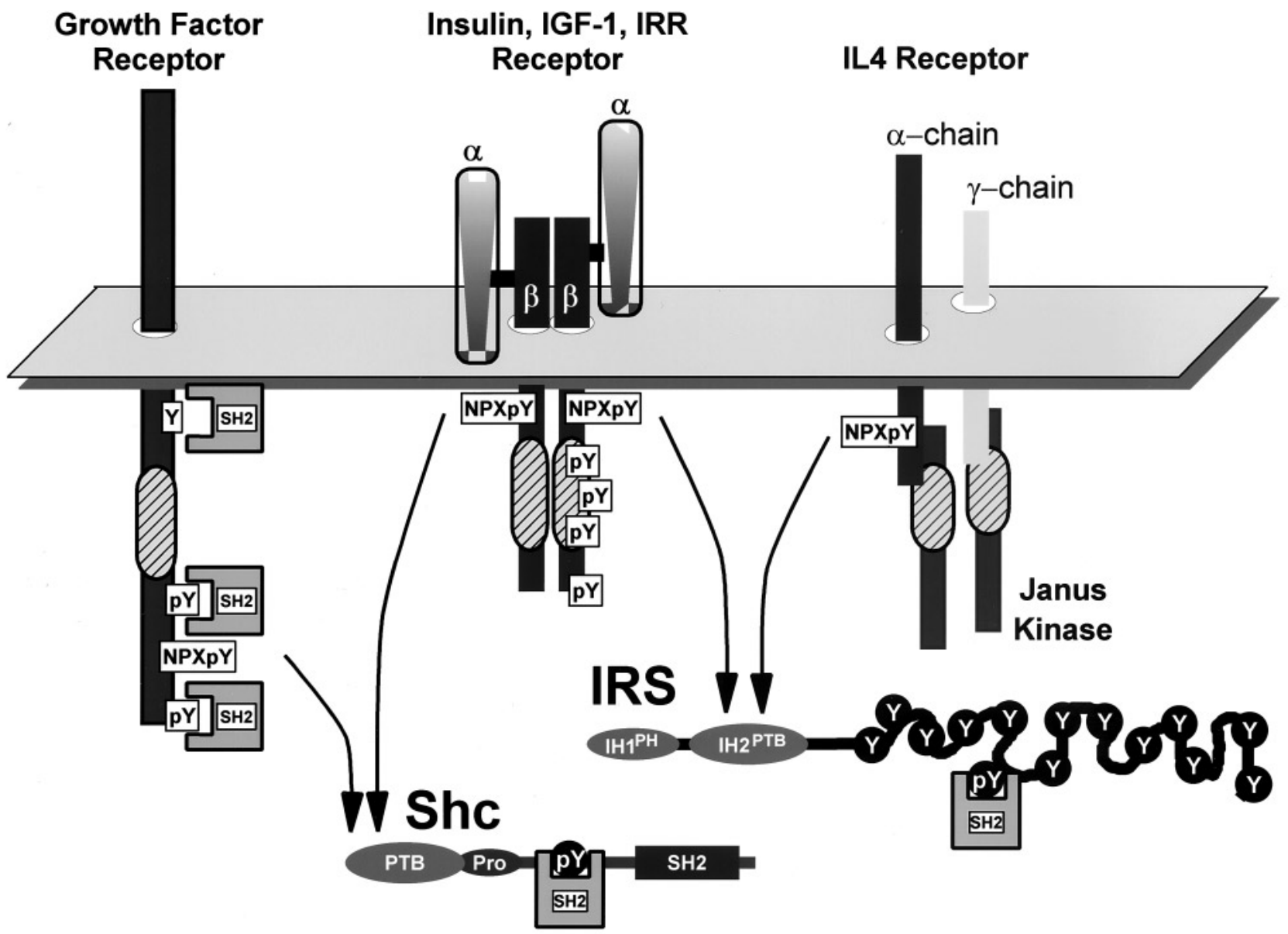

Fig. 3. Schematic diagram depicting three different mechanisms used by the receptor to transmit signals to $\mathrm{SH} 2$-proteins. Many growth factor receptors associate directly through their autophosphorylation sites to $\mathrm{SH} 2$-proteins. The insulin receptor and several cytokine receptors engage IRS-proteins, phosphorylating multiple tyrosine residues which bind SH2-proteins. Like the IRS-proteins, Shc also associates with receptor to provide signalling potential in addition to the endogenous autophosphorylation sites

$\begin{array}{lll}\text { h-IL4r } & 487 & \text { TPLVIAGNPATRSFSNSL } \\ \text { m-IL4r } & 490 & \text { VPLVLADNPAYRSESDCC } \\ \text { r-IL4r } & 483 & \text { VPLVISDNPAYRSFSDFS } \\ \text { h-INSr } & 959 & \text { GPLYASSNPEYLSASDVE } \\ \text { m-INSr } & 979 & \text { GPLYASSNPEYLSASDVF } \\ \text { r-INSr } & 990 & \text { GPLYASSNPEYLSASDVE } \\ \text { h-IGF1r } & 941 & \text { GVLYASVNPEYESAADVY } \\ \text { g-IRRr } & 950 & \text { GTLYTSVNPEYPSASDMY }\end{array}$

Fig. 4. Alignment of the NPXY-motifs in the insulin and IL4r family of receptors

rescues the insulin response, suggesting that the NPXY-motif plays a non-obligatory, albeit very beneficial role to sensitize receptor/substrate coupling [60].
Alignment of the NPXY-motif in the receptors for insulin, IGF-1, and interleukin 4 (IL4), all of which phosphorylate IRS-1, reveals a longer sequence, the LxxxxNPXYxSxSD-motif, which may be the preferred recognition site for IRS-proteins (Fig. 4) [61]. EGF and PDGF receptors lack an NPXY-motif in this context and do not phosphorylate IRS-proteins [62]. Recent studies suggest that the phosphorylated LxxxxNPXYxSxSD-motif binds to the PTB domain in the $\mathrm{NH}_{2}$-terminus of the IRS-proteins and Shc $[63,64]$.

The $\mathrm{COOH}$-terminal tail. Protein tyrosine kinases invariably contain a $\mathrm{COOH}$-terminal tail extending beyond the end of the tyrosine kinase homology region (Fig. 1A). In the EGF and PDGF receptors, the tail contains autophosphorylation sites that bind to $\mathrm{SH} 2-$ proteins, but a similar function for the insulin receptor tail occurs variably in vivo $[65,66]$. The $\mathrm{COOH}-$ terminus of the insulin receptor contains two autophosphorylation sites at $\operatorname{Tyr}_{1316}$ and $\mathrm{Tyr}_{1322}$, as well as the threonine and serine phosphorylation sites. Short deletions in the $\mathrm{COOH}$-terminus which remove the tyrosine and threonine residues $\left(\mathrm{IR}_{\Delta 43}\right)$ either have no effect on or enhance insulin-stimulated autophosphorylation in the other regions; the same applies to insulin-stimulated receptor kinase activity and 
biological activity [67-69]. Even the deletion of 82 amino acids from the $\mathrm{COOH}$-terminus $\left(\mathrm{IR}_{\Delta 82}\right)$ has little effect on substrate phosphorylation and downstream biological effects [70]; however, insulin-stimulated autophosphorylation decreases significantly. Thus, the $\mathrm{COOH}$-terminus appears to regulate insulin signals rather than to recruit SH2-proteins to the receptor.

One of the insulin receptor autophosphorylation sites in the COOH-tail is in a YXXM-motif. This phosphorylation site is a preferred binding motif for the SH2 domains in the PI-3 kinase. Several reports suggest that the PI-3 kinase binds to this site in the activated insulin receptor [71, 72]. However, in cells lacking IRS-proteins, PI-3 kinase does not associate with the insulin receptor kinase, suggesting that in vivo this does not occur [73].

\section{The substrate hypothesis for insulin signal} transduction

Introduction. Early theories of tyrosine kinase signalling focused on intracellular substrate proteins as likely candidates for second messengers. However, it was difficult initially to identify physiologically relevant substrates, and the direct substrate hypothesis was largely set aside [74]. During this interval, the notion that autophosphorylation of the receptor itself was sufficient for signalling was popular. This paradigm was strengthened with the discovery that SH2proteins bind directly to these autophosphorylation sites $[11,75]$. However, the discovery of Shc and our work with IRS-1 reasserted the central role of the substrate hypothesis in several signalling systems $[14,76,77]$.

Insulin receptors phosphorylate multiple proteins. IRS-1 is the best characterized insulin receptor substrate [78]. Although IRS-1 was discovered as a substrate for the insulin receptor, we now know that it is a substrate for several other receptor systems as well, including those in the IL6 family (growth hormone, oncostatin) the IL2 family (IL2, IL4, IL9, IL13 and IL15), and interferons (IFN $\alpha / \beta$ and IFN $\gamma$ ) (Fig. 3). Recently, we purified and cloned the cDNA for IRS-2, which has provided considerably more information regarding the essential features of the IRS-protein substrate family [63]. With the discovery of IRS-2, several additional receptor systems are likely to be discovered that utilize the IRS-proteins to mediate some of the biological responses.

In addition to the IRS-proteins, several other cellular substrates have been described for the insulin receptor. One of the first was pp120, a liver-specific membrane glycoprotein that is tyrosine phosphorylated during insulin stimulation [79]; it is now known to be an ecto-ATPase, perhaps involved in the active movement of small molecules across the liver cell membrane $[80,81]$.

An adipose-specific substrate, pp15, is tyrosine phosphorylated under certain circumstances during insulin stimulation. The pp15 was initially interesting as its phosphorylation was inversely correlated to the rate of glucose uptake; however, it is now known to be identical with 442(aP2), and is phosphorylated at very low stoichiometries [82, 83]. The roles of pp120 and pp15 in insulin action remain enigmatic.

The discovery of tyrosine kinase substrates in other signalling systems has led to the enumeration of other insulin-stimulated tyrosyl phosphoproteins. Vav, a95-kDa proto-oncogene associates with the insulin receptor and is tyrosine phosphorylated during insulin stimulation of certain haematopoietic cells [84]. While the role of Vav in insulin signalling is unclear, it contains several well-known domains for protein-protein interaction, including $\mathrm{SH} 2$ and $\mathrm{SH} 3$ domains, and regions which may contain guanine nucleotide releasing activity for small guanosine 5 '-triphosphate (GTP)-binding proteins [84-86].

Shc plays an important role during insulin signalling. The Shc family is composed of at least three isoforms with molecular weights between 46 and $52 \mathrm{kDa}$ [87]. During stimulation of cells with various growth factors, including insulin, Shc is tyrosine phosphorylated [88]. Shc contains several proteinprotein interaction domains that mediate signalling, including an $\mathrm{SH}$-domain at its $\mathrm{COOH}$-terminus, a PTB-domain at its $\mathrm{NH}_{2}$-terminus, and a collagenlike proline-rich region in the middle of the molecule that contains a tyrosine phosphorylation site in a YINI-motif [77]. The phosphorylated YINI-motif binds to the SH2-domain in Grb-2 and mediates p $21^{\text {ras }}$ GTP-loading [87]. Through this interaction, Shc plays a role in the activation of the mitogen activated protein (MAP) kinase cascade by several growth factor and cytokine receptors, including the insulin receptor $[11,20]$.

Recently, a $115 \mathrm{kDa}$ protein was found in 3T3-L1 adipocytes associated with SHP2 during insulin stimulation [89]. Semi-quantitative analysis by immunoblotting indicates that pp115 may be a major target of SHP2 during insulin stimulation of these cells. By contrast, only a small fraction of SHP2 binds to IRS1. The structure and function of pp115 is unknown, but it may be a novel docking molecule similar to the IRS-1 protein. In this case, pp115 may couple to the insulin receptor through a pleckstrin homologue domain or a phosphotyrosine binding domain with similarity to those in the IRS-proteins.

Finally, adipocytes contain a $60 \mathrm{kDa}$ protein that undergoes tyrosine phosphorylation during insulin stimulation. Previous attempts to clone pp60 were unsuccessful, and considerable confusion has arisen about the nature of this substrate [90-93]. In Chinese hamster ovary $(\mathrm{CHO})$ cells two $60 \mathrm{kDa}$ proteins exist 


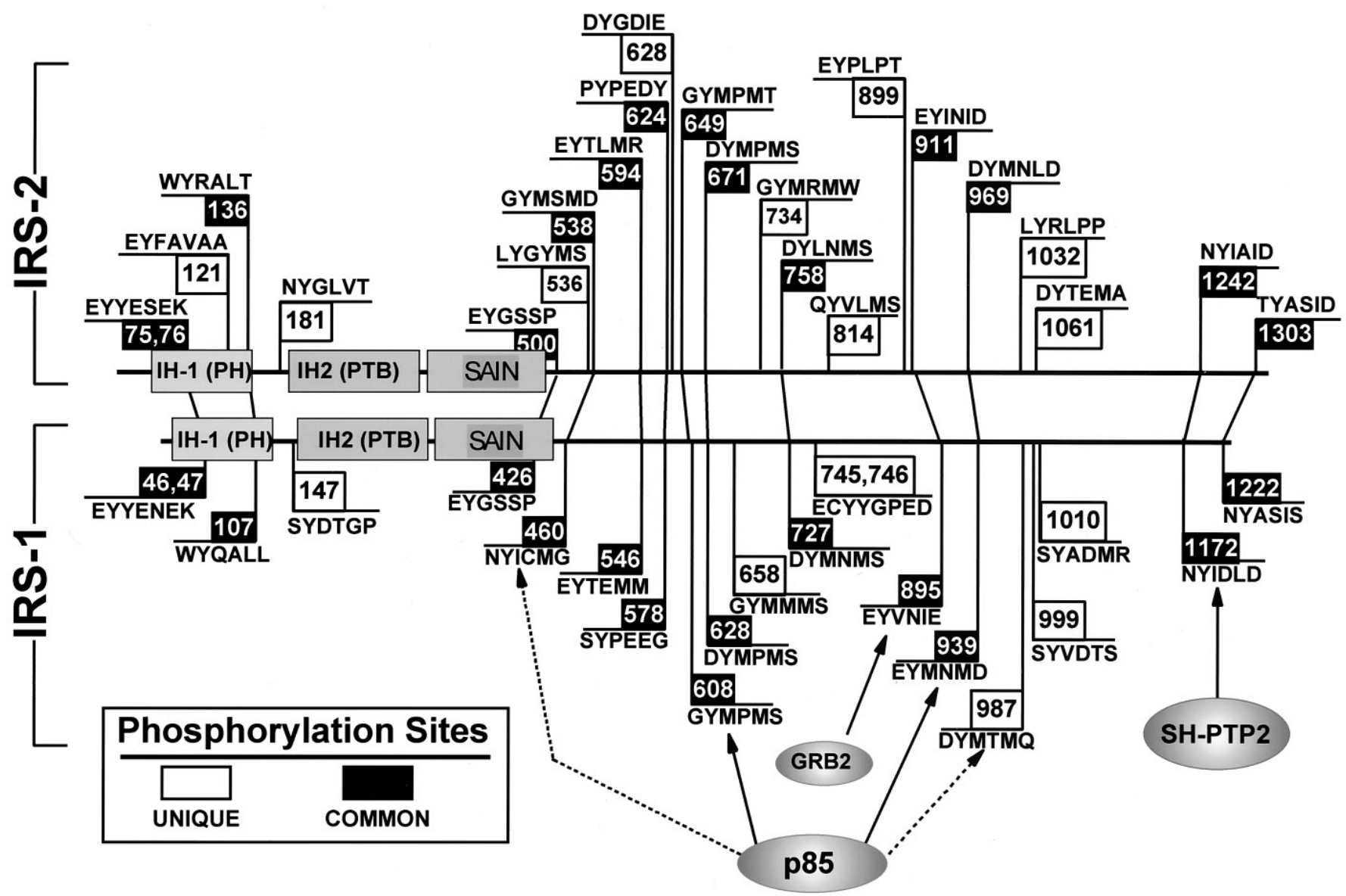

Fig. 5. Schematic diagram of IRS-1 and IRS-2. Two and possibly three conserved modules thought to mediate receptor or other interactions are indicated at the $\mathrm{NH}_{2}$-terminus: $\mathrm{IH} 1^{\mathrm{PH}}$ and $\mathrm{IH} 2{ }^{\mathrm{PTB}}$ and SAIN. Putative tyrosine phosphorylation sites are indicated in the $\mathrm{COOH}$-terminal region. Entirely unique sites are in open boxes, whereas relatively (but not absolutely) conserved motifs are shown in black boxes. IRS-2 is about 100 residues longer than IRS-1

which bind to $221^{\text {ras }}$ GAP or the PI-3 kinase [94]. However, in (HTC) hepatoma cells, pp60 binds strongly to p85 and can be eluted from the p85 immunoprecipitates with phosphopeptides containing YMXM-motifs [95]. These results suggest that pp60 may be a 'mini' IRS-protein, and could be designated pp60irs. Based on our understanding of the structure and function of IRS-1 and IRS-2, pp60 irs is expected to contain either a PTB domain or a pleckstrin homology domain, which are similar to those in the IRS-proteins. The recent clanking of $p p 62^{\text {dok }}$ and IRS-3 supports this hypothesis.

\section{The IRS-proteins}

Structure. IRS-1 was initially detected in insulin-stimulated Fao hepatoma cells by immunoprecipitation with antiphosphotyrosine antibodies; it was originally called pp185 based on migration during SDS-PAGE [96]. It was purified on immobilized antiphosphotyrosine antibodies $(\alpha \mathrm{PY})$ from insulin-stimulated rat liver [97] and 3T3-L1 cells [98], and its cDNA was isolated from rat [76], human [99, 100] and murine [101] sources. The open reading frame predicts a molecular weight of $131 \mathrm{kDa}$; its slow migration on SDS-PAGE is due largely to the high level of phosphorylation of the protein. The IRS- 1 gene contains the entire 5'-untranslated region and protein coding region in a single exon and is localized on chromosome 2q36-37 in humans [99]. IRS-1 mRNA is of low abundance and consists of $6.9 \mathrm{~kb}$ and $6 \mathrm{~kb}$ species in human tissues, and a $9.5 \mathrm{~kb}$ species in rodent tissue. IRS- $1 \mathrm{mRNA}$ is detectable in most human fetal tissues by quantitative PCR after reverse transcription of total RNA [99].

Shortly after the cloning of IRS-1, analysis of pp185 in Fao hepatoma cells revealed another high molecular weight tyrosyl phosphoprotein, designated pp185 ${ }^{\mathrm{HMW}}$ [102]. An IRS resembling pp $185^{\mathrm{HMW}}$ was also observed in FDC-P2 myeloid cells which was designated 4PS (IL4r Phosphoprotein Substrate), since it was initially observed during IL4 stimulation $[103,104]$. An NPXY-motif in the IL4r was essential for IL4 stimulated tyrosine phosphorylation of 4PS, suggesting that it shared a common recognition mechanism with IRS-1 [61]. 
The purification and cloning of 4PS revealed discrete regions of functional homology between IRS-1 and 4PS, suggesting that they were members of the same family of signalling proteins (IRS-proteins); since antibodies against 4PS cross reacted with pp $185^{\mathrm{HMW}}$, both were renamed IRS-2 [63]. The $43 \%$ overall identity between IRS- 1 and IRS-2 is not distributed evenly throughout the molecules: two extended 100-150 amino acid regions in the $\mathrm{NH}_{2}$-terminus, designated the IRS homology-1 (IH1) and IH2 domains, contain higher degrees of identity than the rest of the molecule (65 and $75 \%$, respectively) (Fig. 5).

The IRS-proteins contain multiple tyrosine phosphorylation motifs in the $\mathrm{COOH}$-terminal portion of the molecule (Fig. 5). IRS-1 contains 21 putative tyrosine phosphorylation sites based on general tyrosine kinase specificity (nearby acidic residues and downstream hydrophobic residues) [13, 76]. IRS-1 and IRS-2 show about $35 \%$ identity in this region, and with a few exceptions, the similarity is restricted to the potential tyrosine phosphorylation sites [63]. Fourteen of the 21 potential tyrosine phosphorylation sites from IRS-1 are conserved in IRS-2; four sites contain alternate surrounding sequences; three sites from IRS-1 are not found in IRS-2; and four novel sites exist in IRS-2 (Fig.5).

Detailed studies of tyrosine phosphorylation have been conducted with IRS-1 during insulin stimulation [105]. At least eight tyrosines on IRS-1 undergo phosphorylation by the activated insulin receptor, including residues 608, 628, 939 and 987 which are in YMXM motifs (Fig. 3). The methionine residues at the $\mathrm{Y}^{+1}$ and $\mathrm{Y}^{+3}$ positions facilitate phosphorylation by the insulin receptor [106]; however, other motifs are phosphorylated including $\mathrm{Y}_{460} \mathrm{ICM}, \mathrm{Y}_{895} \mathrm{VNI}$, $\mathrm{Y}_{1172}$ IDL, and $\mathrm{Y}_{1222} \mathrm{ASI}$ [105]. Thirteen additional tyrosine residues may be phosphorylated by the insulin receptor based in proximity to an aspartate or glutamate residue, or by other tyrosine kinases with different selectivity (Fig. 2).

The IRS-proteins also contain over 30 potential serine/threonine phosphorylation sites in motifs recognized by various kinases. Before insulin stimulation IRS-1 is strongly serine phosphorylated [76]. Casein kinase-2 phosphorylates rat IRS-1 at Ser-99 and Thr-502 [107], and preliminary data suggest that purified MAP kinase also phosphorylates recombinant IRS-1 (White, M.F. et al, unpublished). Serine and threonine phosphorylation of IRS-1 appears to inhibit its tyrosine phosphorylation during insulin stimulation [108].

Distribution of IRS-1 and IRS-2. Although IRS-1 and IRS-2 contain common functional domains, they may regulate unique signalling pathways, in part owing to their distinct cellular distribution. IRS-proteins are thought to play an important role during insulin-stimulated glucose transport [109111]. The 3T3-L1 adipocyte is frequently used to study the mechanism of insulin-stimulated glucose uptake, as several metabolic responses acquire insulin sensitivity during their differentiation into adipocytes [112]. Before differentiation, IRS-1 and IRS-2 were barely detectable in the 3T3-L1 fibroblasts by immunoblotting with $\alpha \mathrm{PY}$ during insulin stimulation. After differentiation, the amount of IRS-1 increased dramatically, and insulin strongly stimulated its tyrosine phosphorylation; however, insulin-stimulated tyrosine phosphorylation of IRS-2 remained low. Consistent with this observation, IRS-1 was the predominant phosphorylated IRS-protein in isolated rat adipocytes during insulin stimulation and strongly associated with p85. Based on these results, IRS1 may be the predominant isoform responsible for metabolic signals.

Interaction between the insulin receptor and IRS-proteins. The interaction of the insulin receptor with a limited number of cellular proteins, including IRS-1/ 2 and Shc, suggests that a common mechanism may exist. Recently, the $\mathrm{NH}_{2}$-terminal portion of IRS-1 was shown to mediate an interaction with $\mathrm{Tyr}_{960}$ of the insulin receptor [113-115]. An alignment of the predicted amino acid sequence of murine IRS-1 and IRS-2 revealed two conserved regions at the $\mathrm{NH}_{2}$-terminal end which we call IRS-homology (IH) domains [63]. We designated these $\mathrm{IH}$ domains as $\mathrm{IH} 1^{\mathrm{PH}}$ and $\mathrm{IH} 2^{\mathrm{PTB}}$, to reflect their similarity to pleckstrin homology domains or PTB domains in various proteins (Fig. 5). The IH1 $1^{\mathrm{PH}}$ domain contains 109 amino acid with $69 \%$ identity ( $83 \%$ similarity) between IRS-1 and IRS-2. The IH $2^{\mathrm{PTB}}$ is separated from the $\mathrm{IH} 1^{\mathrm{PH}}$ domain by a 40-residue variable region and is distantly similar to the PTB domain of Shc [63]. The alignment of highest quality defines a region of 160 amino acids with $75 \%$ identity ( $85 \%$ similarity) between IRS-2 and IRS-1, and $15 \%$ identity to the PTB domain in Shc (Fig. 6).

A third region, between residues 313 and 462 of IRS-1 was aligned recently to the PTB domain in Shc, and designated as the 'SAIN' domain [114-116] (Fig. 5). However, this region is poorly conserved between IRS-1 and IRS-2, and appears to be a collection of short conserved motifs including known tyrosine phosphorylation sites. We suspect that this region mediates downstream signalling rather than upstream receptor recognition.

The IH $2^{\text {PTB }}$ domain binds to the phosphorylated NPXY-motif in the insulin and IL4 receptors. Recombinant IH2 $2^{\text {PTB }}$ from IRS-1 binds specifically to the $\mathrm{NH}_{2}{ }^{-L Y A S S N P E}\left(\mathrm{pY}_{960}\right) \mathrm{LSASDV}_{-}{ }_{\mathrm{COOH}}$, previously predicted to mediate the interaction of the insulin receptor and the IL4 receptor with IRS-1 (Fig. 2). Similar results have been observed with these regions of IRS-2 (data not shown). Thus, the $\mathrm{IH} 2^{\mathrm{PTB}}$ in the 


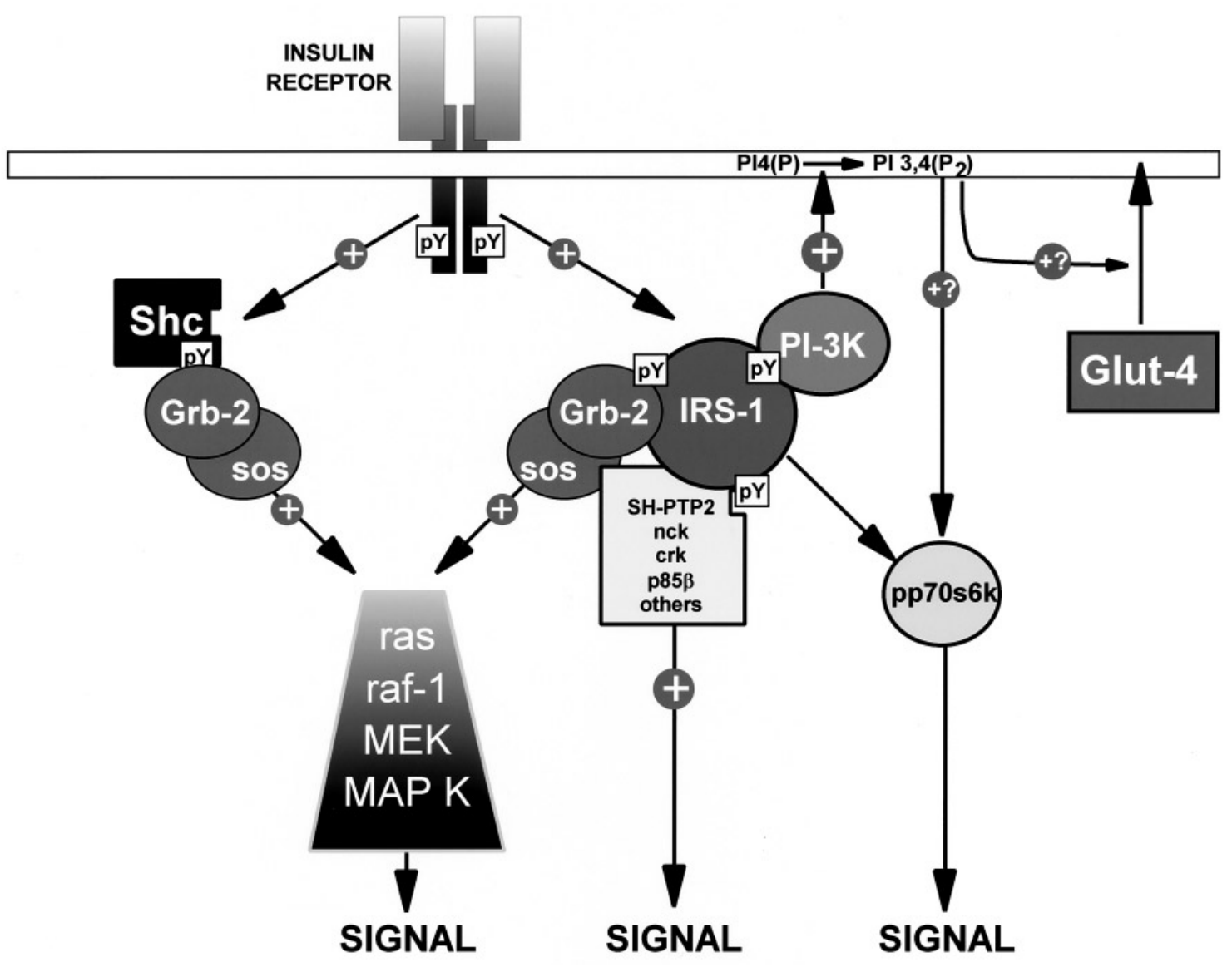

Fig. 6. Schematic diagram of the insulin receptor signalling mechanism. Largely through IRS-proteins, but also involving Shc, the insulin receptor controls various enzyme pathways, including the $\mathrm{p} 70^{\mathrm{s} 6 \mathrm{k}}$, MAP kinase and glucose transporter translocation

IRS-proteins may mediate interactions with receptors by association with phosphorylated $\mathrm{Tyr}_{960}$.

\section{Role of SH 2-proteins during insulin signalling}

Introduction. Unlike many growth factor and cytokine receptors, the insulin receptor binds poorly to SH2-proteins [78]; however, the IRS-proteins, Shc, and possibly a $60-\mathrm{kDa}$ protein that binds to $\mathrm{p} 85$ in rat adipocytes, and pp115 which associates with SHP2 in 3T3-L1 adipocytes, function as interfaces between the receptor and various $\mathrm{SH} 2$-proteins. The binding of SH2-proteins to IRS-1 serves several purposes (Fig. 6): first, enzymes associated with IRS-1 through their $\mathrm{SH} 2$ domains may be activated. This is observed in the case of PI-3 kinase and SHP2. On the other hand, IRS-1 may serve to juxtapose heterogeneous signalling molecules in one location to generate a composite signal. Finally, IRS/SH2-protein complex is mobile and free to move independently of the internalized receptor.
Phosphatidylinositol-3 kinase. The PI 3-kinase was the first SH2-protein found to associate with IRS-1 [76]. It is normally composed of two subunits, a 110$\mathrm{kDa}$ catalytic (p110) subunit and an $85-\mathrm{kDa}(\mathrm{p} 85 \alpha)$ regulatory subunit containing two $\mathrm{SH} 2$ domains. In neuronal cells, $\mathrm{p} 55^{\mathrm{PIK}}$ also regulates p110 [117]. Both $\mathrm{SH} 2$ domains in $\mathrm{p} 85$ and $\mathrm{p} 55^{\mathrm{PIK}}$ associate specifically with phosphorylated IRS-1 in the intact cells and with recombinant IRS- 1 in vitro. IRS- 1 contains at least four sites that interact with the $\mathrm{SH} 2$ domains of p85: $\quad \mathrm{Y}_{608} \mathrm{MPM}>\mathrm{Y}_{939} \mathrm{MNM}>\mathrm{Y}_{987} \mathrm{MTM}$ and $\mathrm{Y}_{460} \mathrm{ICM}$ [105]. The association of $\mathrm{p} 85$ with tyrosine phosphorylated IRS-1 activates the PI-3 kinase [118, 119]. Synthetic peptides containing a single phosphorylated YMXM-motif also activate PI 3'-kinase but are less potent than IRS-1; synthetic peptides containing two phosphorylated YMXM-motifs are equipotent with recombinant IRS-1 [120]. Blood glucose levels are maintained around $5 \mathrm{mmol} / \mathrm{l}$ through the actions of several hormones, including insulin and IGF-1. Glucose stimulates insulin release which promotes glucose transport in skeletal muscle, cardiac myocytes, and adipocytes. Insulin increases glucose transport by causing translocation of GLUT4 from intracellular compartments to the plasma membrane [121]. The effect on GLUT4 translocation reaches a maximum within minutes after insulin stimulation. Two distinct experimental approaches have converged recently to the conclusion that PI-3 kinase is 
necessary, although not necessarily sufficient for insulin-stimulated GLUT4 (and GLUT1) translocation. First, insulin-stimulated glucose uptake is inhibited in fat cells by wortmannin $\left(\mathrm{ED}_{50}=50 \mathrm{nmol} / \mathrm{l}\right)$, a poorly characterized inhibitor of the PI-3 kinase [110]. Alone, these results are questionable because it is impossible to know whether other unknown kinases are also inhibited. However, a p85 mutant $(\Delta \mathrm{p} 85)$ lacking the binding site for p110 inhibits insulin-stimulated glucose uptake (translocation of GLUT1 to the plasma membrane in this case) in CHO cells [109]. Together, these results suggest that the activation of the PI-3 kinase is necessary for insulin-stimulated glucose uptake. However, the activation of PI-3 kinase through other receptors without the stimulation of glucose uptake emphasizes our incomplete state of knowledge [122, 123].

Since IRS-1 is an important upstream element in the regulation of PI-3 kinase by insulin and IGF-1, IRS-1 may play an obligatory role in insulin-stimulated GLUT4 translocation [124]. Disruption of the IRS-1 gene in mice partially supports this conclusion, since insulin-stimulated glucose uptake is reduced by $50 \%[125,126]$. In normal adipocytes, insulin-stimulated PI-3 kinase activity is found in a very low density membrane fraction which also contains a highly phosphorylated cohort of IRS-1 [124]. Interestingly, p85 remains largely in the cytosol during insulin-stimulation, and the total amount in the subcellular fractions is unchanged [124]. The activated PI-3 kinase co-localizes with a $60 \mathrm{kDa}$ phosphotyrosinecontaining protein R3-3 which immunoprecipitates with p85 antibodies [90, 124]. Together with IRS-1, pp60 may regulate PI-3 kinase and glucose influx in adipocytes (126a).

Phosphotyrosine phosphatase, SHP2. SHP2 is an $\mathrm{SH} 2$-containing tyrosine phosphatase expressed ubiquitously in mammalian cells and tissues [127]. It is homologous to D rosophila csw, which mediates the signals from the torso receptor (a PDGF receptor homologue) [128]. Several growth factor receptors, including the EGFr, the PDGFr, and c-kit bind specifically to the SH2 domains in SHP2 [129-132]. Interestingly, the phosphorylated SHP2 serves as an adaptor molecule between the activated PDGFr and the Grb2-Sos complex [133]. During association with these receptors, SHP2 is tyrosine phosphorylated which may increase its catalytic activity. SHP2 is also a target for several non-receptor tyrosine kinases including IL3 and granulocyte/macrophage colonystimulating factor in murine myeloid progenitor-like cells [134]. During association with p210 bcr-abl in several murine cell lines, SHP2 is highly and constitutively tyrosyl phosphorylated [135]. Similarly, SHP2 is constitutively tyrosyl phosphorylated in cells transformed with v-Src, although it does not physically associate with $\mathrm{v}-\mathrm{Src}[129]$.
The precise role of SHP2 in insulin signalling remains unclear, but several reports suggest that it is an essential component in the pathway. Inactive SHP2 inhibits insulin-stimulated MAP kinase and cfos transcription $[136,137]$. This dominant negative effect of inactive SHP2 is partially reversed by co-expression of v-ras or Grb2, indicating that SHP2 may act upstream of Ras [137].

Recently, we discovered that SHP2 associates with $\mathrm{Tyr}_{1146}$ in the regulatory loop of the $\beta$-subunit [57]. This may provide a more stable link between the insulin receptor and IRS-1 that can be obtained through the $\mathrm{IH} 1^{\mathrm{PH}}$ or $\mathrm{IH} 2^{\mathrm{PTB}}$ domain alone. Furthermore, this association may play a role during insulinstimulated glucose uptake [57]. We have also found that IRS-1 mediates insulin-stimulated tyrosine phosphorylation of SHP2 (Shi P, White MF et al, unpublished results). Co-expression of the human insulin receptor with IRS-1 or IRS-2 substantially increases insulin-stimulated phosphorylation of SHP2, as compared to those cells overexpressing insulin receptor alone. Mutations of the binding sites in IRS- 1 abolish the phosphorylation of SHP2 and its in vivo association with IRS-1. These results suggest that SHP2 is placed in close proximity to an activated tyrosine kinase during insulin stimulation. The binding to $\mathrm{Tyr}_{1146}$ in the receptor regulatory loop may facilitate an interaction with the insulin receptor itself. Phosphorylation of SHP2 may further modulate its phosphatase activity or provide a binding site for additional downstream signalling molecules. The phosphorylation of SHP2 by insulin may help clarify its role during insulin signalling.

G RB -2, the insulin-stimulated ras pathway, and the activation of M A P kinase. Grb-2 is a small cytoplasmic protein that contains two $\mathrm{SH} 3$ domains and one $\mathrm{SH} 2$ domain that bind to IRS-1 or Shc. GRB2 is an 'adapter molecule' that links mSOS, a guanine nucleotide exchange factor for $\mathrm{p} 21^{\text {ras }}$, to tyrosyl phosphoproteins such as the EGF receptor, IRS-1 and Shc [133, 138]. During insulin stimulation, both IRS-1 and Shc bind Grb-2; however, the predominant mechanism employed in various insulin-stimulated tissues may depend on the level of insulin receptors and the competition between phosphorylated Shc or $\mathrm{Tyr}_{895}$ in IRS-1 $[20,139,140]$.

The $\mathrm{p} 21^{\mathrm{ras}}$ is active when bound to GTP and inactive when GDP-bound, and while associated with Grb-2, Sos promotes the release of GDP from $\mathrm{p} 21^{\text {ras }}$ enabling GTP binding. While p $21^{\text {ras }}$ has many cellular functions, its ability to control the activation of the MAP Ser/Thr kinases in many cell systems is well established [141]: active p21 $1^{\text {ras }}$ associates with and activates the raf-1 kinase, which phosphorylates and activates MAP kinase-kinase (MEK), which in turn phosphorylates and activates MAP kinase [141]. Thus, engagement of GRB-2/Sos by tyrosyl 
phosphorylated signalling proteins is expected to activate $\mathrm{p} 21^{\mathrm{ras}}$ and the downstream MAP kinase cascade [142].

Our work with single $\mathrm{Tyr} \rightarrow$ Phe point mutations of IRS-1 reveals that the binding of GRB-2 by IRS-1 mediates activation of MAP kinases by insulin in some cells; IRS-1 $1^{\mathrm{F} 895}$, which does not associate with GRB-2, does not mediate the IRS-1-dependent component of MAP kinase activation [20]. The association of Grb-2/Sos with phosphorylated Shc, may provide an alternate pathway for the insulin receptor and a common link for many growth factor receptors. Indeed, while IRS-proteins enhance the insulin-stimulated activation of MAP kinase, they are not required for phosphorylation of Shc, or activation of p $21^{\text {ras }}$ and MAP kinase (Fig. 6). The relative contributions of Shc and IRS-proteins to this cascade are likely to be cell and tissue specific. The IRS-independent tyrosine phosphorylation of Vav may also play a role in the regulation of these pathways [84].

\section{Serine phosphorylation, $\operatorname{TNF} \alpha$, and the regulation of insulin signalling}

The regulation of the insulin receptor kinase by serine phosphorylation is an enigma. Although it is generally accepted that serine phosphorylation inhibits insulin-stimulated tyrosine phosphorylation of the receptor, the mechanism for this effect is not understood [143, 144]. Several serine kinases have been found to mediate serine phosphorylation of the insulin receptor, but protein kinase $\mathrm{C}$ has received the most attention [145-149]. Several sites of serine phosphorylation have been identified in the $\beta$-subunit, but none of them appear to inhibit the receptor kinase.

Serine phosphorylation also plays a role in the regulation of IRS-1 signalling potential. Okadaic acid, a serine phosphatase inhibitor increases serine phosphorylation of IRS-1 in 3T3-L1 adipocytes, which appears to inhibit insulin-stimulated tyrosine phosphorylation; however, the insulin receptor is unaffected [108]. Recently, a role for serine phosphorylation in the regulation of the insulin receptor kinase has emerged from studies on the mechanism of tumour necrosis factor- $\alpha$ (TNF $\alpha)$ inhibition of the insulin receptor kinase [150].

Recent studies have demonstrated that overexpression of TNF $\alpha$ in adipose tissue is a common feature of many different rodent models of obesity [151]. Elevated TNF $\alpha$ expression in adipose tissue is also present in human obesity and correlates strongly with the degree of obesity and the level of hyperinsulinaemia, an indirect measure of insulin resistance [151]. Moreover, neutralization of TNF $\alpha$ in obese and insulin-resistant rats improves insulin signalling and sensitivity of peripheral tissues, demonstrating that $\mathrm{TNF} \alpha$ interferes with insulin action in this disease [152].
The mechanism of TNF $\alpha$-inhibited insulin signalling may occur through its ability to inhibit the tyrosine kinase activity of the insulin receptor [152, 153]. Interestingly, IRS-1 mediates the inhibition of insulin receptor tyrosine kinase activity in vitro, and this effect is dependent upon serine phosphorylation of IRS-1 [150]. The presence of IRS-1 is necessary for the inhibition of insulin receptor signalling by TNFo in intact 32D myeloid cells. 32D cells which lack endogenous IRS-1 are resistant to the effect of TNF $\alpha$ on insulin receptor signalling, whereas cells expressing IRS-1 are very sensitive to TNF $\alpha$. An inhibitory form of IRS-1 is also observed in obese animals, but only when IRS-1 is isolated from the major sites of insulin resistance, muscle and fat. TNF $\alpha$ induces serine phosphorylation of IRS-1 in cultured adipocytes and Fao cells; this appears to inhibit the insulin signal $[150,154]$. These results provide both biochemical and genetic evidence for a novel mechanism by which $\mathrm{TNF} \alpha$ induces insulin resistance and demonstrates an unexpected role for IRS-1 in the attenuation of the insulin receptor signalling, possibly through serine phosphorylation.

\section{Conclusions and perspectives}

With the recent identification of cellular substrates such as the IRS-proteins, and the recent discovery of additional substrates we are in a much better position to understand the role of insulin in molecular terms. But more importantly, as we learn more about the details of the signalling pathways, we begin to appreciate new relationships that may explain puzzling observations. The discovery that TNF $\alpha$ contributes to insulin resistance and that this may be mediated by IRS-protein adds an intriguing twist to the link between obesity and NIDDM. Moreover, the growing list of cytokine receptors that use IRS-proteins to mediate their signals adds another dimension to our understanding of the potential complexity of insulin signalling and the consequences of resistance at the IRSproteins.

\section{References}

1. Lernmark $\AA$ (1995) Insulin-dependent (type I) diabetes: etiology, pathogenesis and natural history. In: DeGroot LJ (ed) Endocrinology, 3rd ed., W. B.Saunders Co. Philadelphia, pp 1423-1435

2. Olefsky JM (1995) Diabetes mellitus (type II): etiology and pathogenesis. In: De Groot LJ (ed) Endocrinology, 3rd ed., W.B.Saunders, Philadelphia, pp 1436-1463

3. Warram JH, Rich SS, Krolewski AS (1995) Epidemiology and genetics of diabetes mellitus. In: Kahn CR, Weir GC (eds) Joslin's diabetes mellitus, 13th ed., Lea \& Febiger, Philadelphia

4. Moller DE, O'Rahilly S (1993) Syndromes of severe insulin resistance: clinical and pathophysiological features. In: 
Moller DE (ed) Insulin resistance, J. Wiley \& Sons, Chichester, pp 49-81

5. Flier JS (1993) An overview of insulin resistance. In: Moller DE (ed) Insulin resistance. John Wiley, New York, pp 1-7

6. Taylor SI, Moller DE (1993) Mutations of the insulin receptor gene. In: Moller DE (ed) Insulin resistance. John Wiley and Sons, Chichester, pp 83-121

7. Hunter T (1995) Protein kinases and phosphatases: the yin and yang of protein phosphorylation and signaling. Cell 80: 225-236

8. Pang DT, Sharma B, Shafer JA, White MF, Kahn CR (1985) Predominance of tyrosine phosphorylation of insulin receptors during the insulin response of intact cells to insulin. J Biol Chem 260: 7131-7136

9. Rosen OM (1987) After insulin binds. Science 237: 14521458

10. Pawson T, Gish GD (1992) SH2 and SH3 domains: from structure to function. Cell 71: 359-362

11. Schlessinger J (1994) SH2/SH3 signaling proteins. Curr Opin Genet Devel 4: 25-30

12. Frattali AL, Pessin JE (1993) Relationship between $\alpha$ subunit ligand occupancy and $\beta$ subunit autophosphorylation of insulin receptor kinases. J Biol Chem 268: 7393-7400

13. Songyang Z, Carraway KL, III, Eck MJ et al. (1995) Catalytic specificity of protein-tyrosine kinases is critical for selective signalling. Nature 373: 536-539

14. Pawson T (1995) Protein modules and signalling network. Nature 373: 573-580

15. Schlessinger J, Ullrich A (1992) Growth factor signaling by receptor tyrosine kinases. Neuron 9: 383-391

16. Backer JM, Myers MG Jr, Shoelson SE et al. (1992) The phosphatidylinositol 3'-kinase is activated by association with IRS-1 during insulin stimulation. EMBO J 11: 3469 3479

17. Kuhne MR, Pawson T, Lienhard GE, Feng G-S (1993) The insulin receptor substrate 1 associates with the $\mathrm{SH} 2$ containing phosphotyrosine phosphatase Syp. J Biol Chem 268: 11479-11481

18. Skolnik EY, Batzer A, Li N et al. (1993) The function of GRB2 in linking the insulin receptor to ras signaling pathways. Science 260: 1953-1955

19. Lee CH, Li W, Nishimura R et al. (1993) Nck associates with the SH2 domain docking proteins IRS-1 in insulin stimulated cells. Proc Natl Acad Sci (USA) 90: 1171311717

20. Myers MG Jr, Wang LM, Sun X et al. (1994) The role of IRS-1/GRB2 complexes in insulin signaling. Mol Cell Biol 14: 3577-3587

21. Seino S, Sieno M, Bell GI (1990) Human insulin-receptor gene. Diabetes 39: 129-133

22. Shier P, Watt VM (1989) Primary structure of a putative receptor for a ligand of the insulin family. J Biol Chem 264: 14605-14608

23. Shoelson SE, White MF, Kahn CR (1988) Tryptic activation of the insulin receptor. J Biol Chem 263: 4852-4860

24. Herrera R, Lebwohl D, Garcia de Herreros A, Kallen RG, Rosen OM (1988) Synthesis, purification and characterization of the cytoplasmic domain of the human insulin receptor using a baculovirus expression system. J Biol Chem 263: 5560-5568

25. Villalba M, Wente SR, Russell DS, Ahn J, Reichelderfer CF, Rosen OM (1989) Another version of the human insulin receptor kinase domain: expression, purification and characterization. Proc Natl Acad Sci (USA) 86: 7848-7852

26. Fuh G, Cunningham BC, Fukunaga R, Nagata S, Goeddel DV, Wells JA (1992) Rational design of potent antagonists to the human growth hormone receptor. Science 256: $1677-1680$

27. Cunningham BC, Ultsch M, de Vos AM, Mulkerrin MG, Clauser KR, Wells JA (1992) Dimerization of the extracellular domain of the human growth hormone receptor by a single hormone molecule. Science $254: 821-825$

28. Schlessinger J (1988) Signal transduction by allosteric receptor oligomerization. TIBS 13: 443-447

29. De Meyts P, Wallach B, Christoffersen CT et al. (1994) The insulin-like growth factor-1 receptor. Structure, ligand-binding mechanism and signal transduction. Horm Res 42: 152-169

30. Lemmon MA, Schlessinger J (1994) Regulation of signal transduction and signal diversity by receptor oligomerization. Trends in Biochemical Sciences 19: 459-463

31. Treadway JL, Morrison BD, Soos MA et al. (1991) Transdominant inhibition of tyrosine kinase activity in mutant insulin/insulin-like growth factor I hybrid receptors. Proc Natl Acad Sci (USA) 88: 214-218

32. Lee J, O'Hare T, Pilch PF, Shoelson SE (1993) Insulin receptor autophosphorylation occurs asymmetrically. J Biol Chem 268: 4092-4098

33. Fratalli AL, Treadway JL, Pessin JE (1992) Transmembrane signaling by the human insulin receptor kinase. Relationship between intramolecular $\beta$ subunit trans- and cis-autophosphorylation and substrate kinase activation. J Biol Chem 267: 19521-19528

34. Shoelson SE, Lee J, Lynch CS, Backer JM, Pilch PF (1993) BpaB25 insulins. Photoactivatable analogues that quantitatively cross-link, radiolabel, and activate the insulin receptor. J Biol Chem 268: 4085-4091

35. DeMeyts P (1995) The structural basis of insulin and insulin-like growth factor-1 receptor binding and negative cooperativity, and its relevance to mitogenic versus metabolic signaling. Diabetologia 37: S135-S148

36. Bajaj M, Waterfield MD, Schlessinger J, Taylor WR, Blundell T (1987) On the tertiary structure of the extracellular domains of epidermal growth factor and insulin receptors. Biochim Biophys Acta 916: 2206

37. Schlessinger J (1988) Signal transduction by allosteric receptor oligomerization. Trends Biochem Sci 13: 443-447

38. Riedel H, Dull TJ, Schlessinger J, Ullrich A (1986) A chimaeric receptor allows insulin to stimulate tyrosine kinase activity of epidermal growth factor receptor. Nature 324: $68-70$

39. Riedel H, Dull TJ, Schlessinger J, Ullrich A (1989) Cytoplasmic domains determine signal specificity, cellular characteristics and influence ligand binding of epidermal factor and insulin receptors. EMBO J 8: 2943-2954

40. Frattali AL, Treadway JL, Pessin JE (1991) Evidence supporting a passive role for the insulin receptor transmembrane domain in insulin-dependent signal transduction. J Biol Chem 266: 9829-9834

41. Ihle JN, Morishita K, Matsugi T, Bartholomew C (1990) Insertional mutagenesis and transformation of hematopoietic stem cells. Prog Clin Biol Res 352: 329-337

42. Cheatham B, Shoelson SE, Yamada K, Goncalves E, Kahn CR (1993) Substitution of the erbB-2 oncoprotein transmembrane domain activates the insulin receptor and modulates the action of insulin and insulin-receptor substrate 1. Proc Natl Acad Sci (USA) 90: 7336-7340

43. Longo N, Shuster RC, Griffin LD, Langley SD, Elsas LJ (1992) Activation of insulin receptor signaling by a single amino acid substitution in the transmembrane domain. $\mathbf{J}$ Biol Chem 267: 12416-12419

44. Cunningham BC, Ultsch M, de Vos AM, Mulkerrin MG, Clauser KR, Wells JA (1991) Dimerization of the 
extracellular domain of the human growth hormone receptor by a single hormone molecule. Science 254: 821-826

45. Feener EP, Backer JM, King GL, Wilden PA, Sun X, Kahn CR, White MF (1993) Insulin stimulates serine and tyrosine phosphorylation in the juxtamembrane region of the insulin receptor. J Biol Chem 268: 11256-11264

46. White MF, Kahn CR (1994) The insulin signaling system. J Biol Chem 269: 1-5

47. McClain D, Maegawa H, Levy J et al. (1988) Properties of a human insulin receptor with a $\mathrm{COOH}$-terminal truncation. I. Insulin binding, autophosphorylation and endocytosis. J Biol Chem 263: 8904-8912

48. Maegawa H, McClain D, Freidneberg G et al. (1988) Properties of a human insulin receptor with a $\mathrm{COOH}$-terminal truncation II. Truncated receptors have normal kinase activity but are defective in signaling metabolic effects. J Biol Chem 263: 8912-8917

49. Chou CK, Dull TJ, Russell DS, Gherzi R, Lebwohl D, Ullrich A, Rosen OM (1987) Human insulin receptors mutated at the TP-binding site lack protein tyrosine kinase activity and fail to mediate postreceptor effects of insulin. J Biol Chem 262: 1842-1847

50. McClain DA, Maegawa H, Lee J, Dull TJ, Ullrich A, Olefsky JM (1987) A mutant insulin receptor with defective tyrosine kinase displays no biological activity and does not undergo endocytosis. J Biol Chem 262: 14663-14671

51. Odawara M, Kadowaki T, Yamamoto R et al. (1989) Human diabetes associated with a mutation in the tyrosine kinase domain of the insulin receptor. Science 245: 66-68

52. Moller DE, Yokota A, White MF, Pazianos AG, Flier JS (1990) A naturally occurring mutation of insulin receptor alanine 1134 impairs tyrosine kinase function and is associated with dominantly inherited insulin resistance. J Biol Chem 265: 14979-14985

53. White MF, Shoelson SE, Ketumann H, Kahn CR (1988) A cascade of tyrosine autophosphorylation in the $\beta$-subunit activates the insulin receptor. J Biol Chem 263: 2969-2980

54. Vogt B, Carrascosa JM, Ermel B, Ullrich A, Haring HU (1991) The two isotypes of the human insulin receptor (HIR-A and HIR-B) follow different internalization kinetics. Biochem Biophys Res Commun 177: 1013-1018

55. Wilden PA, Siddle K, Haring E, Backer JM, White MF, Kahn CR (1992) The role of insulin receptor kinase domain autophosphorylation in receptor-mediated activities. J Biol Chem 267: 13719-13727

56. Issad T, Tavare JM, Denton RM (1991) Analysis of insulin receptor phosphorylation sites in intact rat liver cells by two-dimensional phosphopeptide mapping. Predominance of the tris-phosphorylated form of the kinase domain after stimulation by insulin. Biochem 275: 15-21

57. Kharitonenkov A, Schnekenburger J, Chen Z et al. (1995) Adapter function of PTP1D in insulin receptor/IRS-1 interaction. J Biol Chem 270: 29189-29193

58. White MF, Livingston JN, Backer JM, Lauris V, Dull TJ, Ullrich A, Kahn CR (1988) Mutation of the insulin receptor at tyrosine 960 inhibits signal transmission but does not affect its tyrosine kinase activity. Cell 54: 641-649

59. Kaburagi Y, Momomura K, Yamamoto-Honda R et al. (1993) Site-directed mutatgenesis of the juxtamembrane domain of the human insulin receptor. J Biol Chem 268: 16610-16622

60. Chen D, Van Horn DJ, White MF, Backer JM (1995) Insulin receptor substrate 1 rescues insulin action in $\mathrm{CHO}$ cells expressing mutant insulin receptors that lack a juxtamembrane NPXY motif. Mol Cell Biol 15: 4711-4717

61. Keegan AD, Nelms K, White M, Wang LM, Pierce JH, Paul WE (1994) An IL-4 receptor region containing an insulin receptor motif is important for IL-4-mediated IRS-1 phosphorylation and cell growth. Cell 76: 811-820

62. Myers MG Jr, Cheatham B, Fisher TL, Jachna BR, Kahn CR, Backer JM, White MF (1996) Common and distinct elements in insulin and PDGF signaling. Ann N Y Acad Sci 766: 369-387

63. Sun XJ, Wang LM, Zhang Y et al. (1995) Role of IRS-2 in insulin and cytokine signalling. Nature 377: 173-177

64. Wolf G, Trub T, Ottingor E et al. (1995) PTB domains of IRS-1 and Shc have distinct but overlapping binding specificities. J Biol Chem 270: 27407-27410

65. Backer JM, Myers MG Jr, Sun X, Chin DJ, Shoelson SE, Miralpeix M, White MF (1993) Association of IRS-1 with the insulin receptor and the phosphatidylinositol 3'-kinase. Formation of binary and ternary signaling complexes in intact cells. J Biol Chem 268: 8204-8212

66. Staubs PA, Reichart DR, Saltiel AR et al. (1994) Localization of the insulin receptor binding sites for the $\mathrm{SH} 2$ domain proteins p85, syp, and GAP. J Biol Chem 269: 27186-27192

67. Myers MG Jr, Backer JM, Siddle K, White MF (1991) The insulin receptor functions normally in Chinese hamster ovary cells after truncation of the C-terminus. J Biol Chem 266: 10616-10623

68. Thies RS, Ullrich A, McClain DA (1989) Augmentated mitogenesis and impaired metabolic signaling mediated by a truncated insulin receptor. J Biol Chem 264: 12820-12825

69. Pang L, Milarski KL, Ohmichi M, Takata Y, Olefsky JM, Saltiel AR (1994) Mutation of the two carboxyl-terminal tyrosines in the insulin receptor results in enhanced activation of mitogen-activated protein kinase. J Biol Chem 269: 10604-10608

70. Yamamoto-Honda R, Kadowaki T, Momomura K et al. (1993) Normal insulin receptor substrate-1 phosphorylation in autophosphorylation-defective truncated insulin receptor. J Biol Chem 268: 16859-16865

71. Levy-Toledano R, Taouis M, Blaettler DH, Gorden P, Taylor SI (1994) Insulin-induced activation of phosphatidyl inositol 3-kinase. J Biol Chem 269: 31178 (Abstract)

72. Van Horn DJ, Myers MG Jr, Backer JM (1994) Direct activation of the phosphatidylinositol 3'-kinase by the insulin receptor. J Biochem 269(1): 29-32

73. Myers MG Jr, Grammer TC, Wang LM et al. (1994) IRS-1 mediates PI 3 -kinase and $\mathrm{p} 70^{\mathrm{s} 6 \mathrm{k}}$ signaling during insulin; IGF-1 and IL-4 stimulation. J Biol Chem 269: 2878328789

74. Koch CA, Anderson DJ, Moran MF, Ellis C, Pawson T (1991) SH2 and SH3 domains: elements that control interactions of cytoplasmic signaling proteins. Science 252: 668-674

75. Schlessinger J (1993) How receptor tyrosine kinases activate Ras. Trends Biochem Sci 18: 273-275

76. Sun X, Rothenberg P, Kahn CR et al. (1991) The structure of the insulin receptor substrate IRS-1 defines a unique signal transduction protein. Nature 352: 73-77

77. Pelicci GL, Lanfrancone L, Grignani F et al. (1992) A novel transforming protein (SHC) with an $\mathrm{SH} 2$ domain is implicated in mitogenic signal transduction. Cell 70: 93104

78. Myers MG Jr, White MF (1995) New frontiers in insulin receptor substrate signaling. Trends Endocrinol Metab 6: 209-215

79. Perrotti N, Accili D, Marcus Samuels B, Rees Jones RW, Taylor SI (1987) Insulin stimulates phosphorylation of a $120-\mathrm{kDa}$ glycoprotein substrate (pp120) for the receptorassociated protein kinase in intact $\mathrm{H}-35$ hepatoma cells. Proc Natl Acad Sci (USA) 84: 3137-3140 
80. Margolis RN, Schell MJ, Taylor SI, Hubbard AL (1990) Hepatocyte plasma membrane ecto-ATPase (pp120/ HA4) is a substrate for tyrosine kinase activity of the insulin receptor. Biochem Biophys Res Commun 166: 562-566

81. Najjar SM, Accili D, Philippe N, Jernberg J, Margolis R, Taylor SI (1993) pp120/ecto-ATPase, an endogenous substrate of the insulin receptor tyrosine kinase, is expressed as two variably spliced isoforms. J Biol Chem 268: 12011206

82. Bernier M, Laird DM, Lane MD (1988) Effect of vanadate on the cellular accumulation of pp15, an apparent product of insulin receptor tyrosine kinase action. J Biol Chem 263: 13626-13634

83. Hresko RC, Bernier M, Hoffman RD et al. (1988) Identification of phosphorylated $422(\mathrm{aP} 2)$ protein as $\mathrm{pp} 15$, the 15-kilodalton target of the insulin receptor tyrosine kinase in 3T3-L1 adipocytes. Proc Natl Acad Sci (USA) 85: 88358839

84. Uddin S, Katzav S, White MF, Platanias LC (1995) Insulin-dependent tyrosine phosphorylation of the vav protooncogene product in cells of hematopoietic origin. J Biol Chem 270: 7712-7716

85. Gulbins E, Coggeshall KM, Baier G, Katzav S, Burn P, Altman A (1993) Tyrosine kinase-stimulated guanine nucleotide exchange activity of Vav in T cell activation [see comments]. Science 260: 822-825

86. Hu P, Margolis B, Schlessinger J (1993) Vav: a potential link between tyrosine kinases and ras-like GTPases in hematopoietic cell signaling. Bio Essays 15: 179-183

87. Pellici G, Lanfrancone L, Grignani F et al. (1992) A novel transforming protein (SHC) with an $\mathrm{SH} 2$ domain is implicated in mitogenic signal transduction. Cell 70: 93-104

88. Skolnik EY, Lee CH, Batzer A et al. (1993) The SH2/SH3 domain-containing protein GRB2 interacts with tyrosinephosphorylated IRS-1 and Shc: implications for insulin control of ras signalling. EMBO J 12: 1929-1936

89. Yamauchi K, Ribon V, Saltiel AR, Pessin JE (1995) Identification of the major SHPTP2-binding protein that is tyrosine-phosphorylated in response to insulin. J Biol Chem 270: 17716-17722

90. Lavan BE, Lienhard GE (1993) The insulin-elicited 60$\mathrm{kDa}$ phosphotyrosine protein in rat adipocytes is associated with phosphatidylinositol 3-kinase. J Biol Chem 268: 5921-5928

91. Haring HU, White MF, Machicao F, Ermel B, Schleicher E, Obermaier B (1987) Insulin rapidly stimulates phosphorylation of a $46-\mathrm{kDa}$ membrane protein on tyrosine residues as well as phosphorylation of several soluble proteins in intact fat cells. Proc Natl Acad Sci (USA) 84: 113-117

92. Momomura K, Tobe K, Seyama Y, Takaku F, Kasuga M (1988) Insulin-induced tyrosine phosphorylation in intact rat adipocytes. Biochem Biophys Res Commun 155: 1181-1186

93. Steele-Perkins G, Roth RA (1990) Insulin-mimetic antiinsulin receptor monoclonal antibodies stimulate receptor kinase activity in intact cells. J Biol Chem 265: 9458-9463

94. Hosomi Y, Shii K, Ogawa W et al. (1994) Characterization of a 60-kilodalton substrate of the insulin receptor kinase. J Biol Chem 269: 11498-11502

95. Milarski KL, Lazar DF, Wiese RJ, Saltiel AR (1995) Detection of a $60 \mathrm{kDa}$ tyrosine-phosphorylated protein in insulin-stimulated hepatoma cells that associates with the $\mathrm{SH} 2$ domain of phosphatidylinositol 3-kinase. Biochem $\mathbf{J}$ 308: 579-583

96. White MF, Maron R, Kahn CR (1985) Insulin rapidly stimulates tyrosine phosphorylation of a Mr 185,000 protein in intact cells. Nature 318: 183-186
97. Rothenberg PL, Lane WS, Karasik A, Backer J, White M, Kahn CR (1991) Purification and partial sequence analysis of pp185, the major cellular substrate of the insulin receptor tyrosine kinase. J Biol Chem 266: 8302-8311

98. Keller SR, Kitagawa K, Aebersold RH, Lienhard GE, Garner CW (1991) Isolation and characterization of the 160,000-Da phosphotyrosyl protein, a putative participant in insulin signaling. J Biol Chem 266: 12817-12820

99. Araki E, Sun X, Haag BL et al. (1993) Human skeletal muscle insulin receptor substrate-1: characterization of the cDNA, gene and chromosomal localization. Diabetes 42: 1041-1054

100. Nishiyama M, Wands JR (1992) Cloning and increased expression of an insulin receptor substrate-1-like gene in human hepatocellular carcinoma. Biochem Biophys Res Commun 183: 280-285

101. Keller SR, Aebersold RH, Garner CW, Lienhard GE (1993) The insulin-elicited $160 \mathrm{kDa}$ phosphotyrosine protein in mouse adipocytes in an insulin receptor substrate 1: identification by cloning. BBA 1172: 323-326

102. Miralpeix M, Sun X, Backer JM, Myers MG Jr, Araki E, White MF (1992) Insulin stimulates tyrosine phosphorylation of multiple high molecular weight substrates in FAO hepatoma cells. Biochemistry 31: 9031-9039

103. Wang LM, Myers MG Jr, Sun X, Aaronson SA, White MF, Pierce JH (1993) IRS-1: Essential for insulin and IL4-stimulated mitogenesis in hematopoietic cells. Science 261: 1591-1594

104. Wang LM, Keegan AD, Li W et al. (1993) Common elements in IL4 and insulin signaling pathways in factor dependent hematopoietic cells. Proc Natl Acad Sci (USA) 90: 4032-4036

105. Sun X, Crimmins DL, Myers MG Jr, Miralpeix M, White MF (1993) Pleiotropic insulin signals are engaged by multisite phosphorylation of IRS-1. Mol Cell Biol 13: $7418-7428$

106. Shoelson SE, Chatterjee S, Chaudhuri M, White MF (1992) YMXM motifs of IRS-1 define the substrate specificity of the insulin receptor kinase. Proc Natl Acad Sci (USA) 89: 2027-2031

107. Tranisijevik M, Myers MG Jr, Thomas RS, Crimmons D, White MF, Sacks D (1993) Phosphorylation of the insulin receptor substrate IRS-1 by casein kinase II. J Biol Chem 268: 18157-18166

108. Jullien D, Tanti JF, Heydrick SJ, Gautier N, Gremeaux T, Van Obberghen E, LeMarchand-Brustel Y (1993) Differential effects of okadaic acid on insulin-stimulated glucose and amino acid uptake and phosphatidylinositol 3-kinase activity. J Biol Chem 268: 15246-15251

109. Hara K, Yonezawa K, Sakaue H et al. (1994) 1-Phosphatidylinositol 3-kinase activity is required for insulin-stimulated glucose transport but not for ras activation in $\mathrm{CHO}$ cells. Proc Natl Acad Sci (USA) 91: 7415-7419

110. Okada T, Kawano Y, Sakakibara T, Hazeki O, Ui M (1994) Essential role of phosphatidylinositol 3-kinase in insulin-induced glucose transport and antilipolysis in rat adipocytes. J Biochem 269(5): 3568-3573

111. Quon MJ, Butte AJ, Zarnowski MJ, Sesti G, Cushman SW, Taylor SI (1994) Insulin receptor substrate 1 mediates the stimulatory effect of insulin on GLUT4 translocation in transfected rat adipose cells. J Biol Chem 269: 27920-27924

112. Rosen OM, Smith CJ, Fung C, Rubin CS (1978) Development of hormone receptors and hormone responsiveness in vitro. $\mathrm{J}$ Biol Chem 253: 7579-7853

113. Myers MG Jr, Grammer TC, Brooks J et al. (1995) The pleckstrin homology domain in IRS-1 sensitizes insulin signaling. J Biol Chem 270: 11715-11718 
114. Gustafson TA, He W, Craparo A, Schaub CD, O’Neill TJ (1995) Phosphotyrosine-dependent interaction of Shc and IRS-1 with the NPEY motif of the insulin receptor via a novel non-SH2 domain. Mol Cell Biol 15: 2500-2508

115. Craparo A, O'Neill TJ, Gustafson TA (1995) Non-SH2 domains within the insulin receptor substrate-1 and SHC mediate their phosphotyrosine-dependent interaction with the NPEY motif of the insulin-like growth factor 1 receptor. J Biol Chem 270: 15639-15643

116. O'Neill TJ, Craparo A, Gustafson TA (1994) Characterization of an interaction between insulin receptor substrate- 1 and the insulin receptor by using the two-hybrid system. Mol Cell Biol 14: 6433-6442

117. Pons S, Asano T, Glasheen E et al. (1995) The structure and function of $\mathrm{p} 55^{\mathrm{PIK}}$ reveals a new regulatory subunit for the phosphatidylinositol-3 kinase. Mol Cell Biology 15: 4453-4465

118. Ruderman N, Kapeller R, White MF, Cantley LC (1990) Activation of phosphatidylinositol-3-kinase by insulin. Proc Natl Acad Sci (USA) 87: 1411-1415

119. Myers MG Jr, Backer JM, Sun X et al. (1992) IRS-1 activates the phosphatidylinositol 3'-kinase by associating with the src homology 2 domains of p85. Proc Natl Acad Sci (USA) 89: 10350-10354

120. Rordorf-Nikolic T, Van Horn DJ, Chen D, White MF, Backer JM (1995) Regulation of phosphatidylinositol 3kinase by tyrosyl phosphoproteins. Full activation requires occupancy of both $\mathrm{SH} 2$ domains in the $85 \mathrm{kDa}$ regulatory subunit. J Biol Chem 270: 3662-3666

121. Lienhard GE, Slot JW, James DE, Mueckler MM (1992) How cells absorb glucose. Scientific American 266: 8691

122. Saltiel AR, Ohmichi M (1993) Pleiotropic signaling from receptor tyrosine kinases. Curr Opin Neurobiol 3: 352-359

123. Isakoff SJ, Taha C, Rose E, Klip A, Skolnik EY (1995) Activation of PI-3 kinase via IRS-1 or IRS-1 independent pathways is not sufficient to stimulate glucose uptake in insulin sensitive cells. Diabetes 44: 18A (Abstract)

124. Kelly KL, Ruderman NB (1993) Insulin-stimulated phosphatidylinositol 3-kinase: association with a $185-\mathrm{kDa}$ tyrosine-phosphorylated protein (IRS-1) and localization in a low density membrane vesicle. J Biol Chem 268: 4391-4398

125. Araki E, Lipes MA, Patti ME, Bruning JC, Haag B, III, Johnson RS, Kahn CR (1994) Alternative pathway of insulin signalling in mice with targeted disruption of the IRS-1 gene. Nature 372: 186-190

126. Tamemoto H, Kadowaki T, Tobe K et al. (1994) Insulin resistance and growth retardation in mice lacking insulin receptor substrate-1. Nature 372: 182-186

126a. Lavan BE, Lane WS, Lienhard GE (1997) The 60-kDa phosphotyrosine protein in insulin-treated adipocytes is a new member of the insulin receptor substrate family. J Biol Chem 272 (17): 11439-43

127. Freeman RM, Plutzky J, Neel BG (1992) Identification of a human src homology 2-containing protein-tyrosinephosphatase: a putative homolog of D rosphila corkscrew. Proc Natl Acad Sci (USA) 89: 11239-11243

128. Perkins LA, Larsen I, Perrimon N (1992) Corkscrew encodes a putative protein tyrosine phosphatase that functions to transduce the terminal signal from the receptor tyrosine kinase torso. Cell 12: 225-236

129. Feng G-S, Hui C-C, Pawson T (1993) SH-2 containing phosphotyrosine phosphatase as a target of protein-tyrosine kinase. Science 259: 1607-1614

130. Lechleider RJ, Freeman RM, Neel BG (1993) Tyrosyl phosphorylation and growth factor receptor association of the human corkscrew homologue, SHPTP2. J Biol Chem 268: 13434-13438

131. Lechleider RJ, Sugimoto S, Bennett AM et al. (1993) Activation of the SH2-containing phosphotyrosine phosphatase SH-PTP2 by its binding site, phosphotyrosine 1009 , on the human platelet-derived growth factor receptor B. J Biol Chem 268: 21478-21481

132. Tauchi T, Feng GS, Marshall MS, Shen R, Mantel C, Pawson T, Broxmeyer HE (1994) The ubiquitously expressed Syp phosphatase interacts with c-kit and Grb2 in hematopoietic cells. J Biol Chem 269: 25206-25211

133. Li N, Batzer A, Daly R et al. (1993) Guanine-nucleotidereleasing factor mSos1 binds to Grb2 and links receptor tyrosine kinases to ras signalling. Nature 363: 85-88

134. Welham MJ, Dechert U, Leslie KB, Jirik F, Schrader JW (1994) Interleukin (IL)-3 and granulocyte/macrophage colony-stimulating factor, but not IL-4, induce tyrosine phosphorylation, activation, and association of SHPTP2 with Grb2 and phosphatidylinositol 3-kinase. J Biol Chem 269: 23764-23768

135. Tauchi T, Feng GS, Shen R, Song HY, Donner D, Pawson T, Broxmeyer HE (1994) SH2-containing phosphotyrosine phosphatase Syp is a target of p210bcr-ab1 tyrosine kinase. J Biol Chem 269: 15381-15387

136. Yamauchi K, Milarski KL, Saltiel AR, Pessin JE (1995) Protein-tyrosine-phosphatase SHPTP2 is a required positive effector for insulin downstream signaling. Proc Natl Acad Sci (USA) 92: 664-668

137. Noguchi T, Matozaki T, Horita K, Fujioka Y, Kasuga M (1994) Role of SH-PTP2, a protein-tyrosine phosphatase with Src homology 2 domains, in insulin-stimulated ras activation. Mol Cell Biol 14: 6674-6682

138. Simon MA, Dodson GS, Rubin GM (1993) An SH3-SH2$\mathrm{SH} 3$ protein is required for $\mathrm{p} 21^{\text {ras1 }}$ activation and binds to sevenless and Sos proteins in vitro. Cell 73: 169-177

139. Rose DW, Saltiel AR, Majumdar M, Decker SJ, Olefsky JM (1994) Insulin receptor substrate 1 is required for insulin-mediated mitogenic signal transduction. Proc Natl Acad Sci (USA) 91: 797-801

140. Sasaoka T, Draznin B, Leitner JW, Langlois WJ, Olefsky JM (1994) Shc is the predominant signaling molecule coupling insulin receptors to activation of guanine nucleotide releasing factor and p21ras formation. J Biol Chem 269: 10734-10738

141. Roberts TM (1992) A signal chain of events. Nature 360: 534-535

142. Lowenstein EJ, Daly RJ, Batzer AG et al. (1992) The SH2 and $\mathrm{SH} 3$ domain-containing proteins GRB2 links receptor tyrosine kinases to ras signaling. Cell 70: 431-442

143. Takayama S, White MF, Kahn CR (1988) Phorbol ester-induced serine phosphorylation of the insulin receptor decreases its tyrosine kinase activity. J Biol Chem 263: 3440-3447

144. Stadtmauer L, Rosen OM (1986) Increasing the cAMP content of IM-9 cells alters the phosphorylation state and protein kinase activity of the insulin receptor. J Biol Chem 261: 3402-3407

145. Chin JE, Liu F, Roth RA (1994) Activation of protein kinase c gamma inhibits insulin-stimulated tyrosine phosphorylation of insulin receptor substrate-1. Mol Endocrinol 8(1): 51-58

146. Liu F, Roth RA (1994) Identification of serines-967/968 in the juxtamembrane region of the insulin receptor as insulin-stimulated phosphorylation sites. J Biochem 298: 1-7 (Abstract)

147. Liu F, Roth RA (1994) Identification of serines-1035/1037 in the kinase domain of the insulin receptor as protein 
kinase C-alpha mediated phosphorylation sites. FEBS Letters 352: 389-392

148. Liu F, Roth RA (1994) Insulin-stimulated tyrosine phosphorylation of protein kinase $\mathrm{C}$ alpha: evidence for direct interaction of the insulin receptor and protein kinase $\mathrm{C}$ in cells. Biochem Biophys Res Commun 200: 1570-1577

149. Chin JE, Dickens M, Tavare JM, Roth RA (1993) Overexpression of protein kinase $\mathrm{C}$ isoenzymes alpha, beta I, gamma, and epsilon in cells overexpressing the insulin receptor. Effects on receptor phosphorylation and signaling. J Biol Chem 268: 6338-6347

150. Hotamisligil GS, Budavari A, Donovan A, Ellis R, White MF, Spiegelman BM (1996) Inhibition of insulin receptor signaling by TNF $\alpha$-induced phosphorylation of IRS-1: a mechanistic model for insulin resistance. Science 665-668
151. Hotamisligil GS, Arner P, Caro JF, Atkinson RL, Spiegelman BM (1995) Increased adipose tissue expression of tumor necrosis factor- $\alpha$ in human obesity and insulin resistance. J Clin Invest 95: 2409-2415

152. Hotamisligil GS, Budavari A, Murray D, Spiegelman BM (1994) Reduced tyrosine kinase activity of the insulin receptor in obesity-diabetes. Central role of tumor necrosis factor-alpha. J Clin Invest 94: 1543-1549

153. Feinstein R, Kanety H, Papa MZ, Lunenfeld B, Karasik A (1994) Tumor necrosis factor-alpha suppressed insulin-induced tyrosine phosphorylation of insulin receptor and its substrates. J Biol Chem 268: 26055-26058

154. Kanety H, Feinstein R, Papa MZ, Hemi R, Karasik A (1995) Tumor necrosis factor $\alpha$-induced phosphorylation of insulin receptor substrate-1 (IRS-1). J Biol Chem 270: 23780-23784 